\title{
AHMAD JAAM'S MYSTICAL, MORAL AND PHILOSOPHICAL THOUGHTS
}

\section{PENSAMENTOS MÍSTICOS, MORAIS E FILOSÓFICOS DE AHMAD JAAM}

\author{
Saeed Reza Yousefi ${ }^{1}$
}

\begin{abstract}
If we look through the history of mankind, we will realize that this planet has been the birthplace of human beings who by presenting their valuable thoughts have created changes in the life of humanity. One of them is Ahmad Jaam, who Less attention has been paid to introducing his moral, philosophical and philosophical thoughts, which this has led to the failure to identify and introducing him in some of the important books of theosophical men and Iranian thinkers. Therefore, this article prompted the introduction of his thoughts and mentality. Ahmad Jaam is a social thinker and reformer and a righteous Sufi and pure believer, a liberated man with ethical and philosophical and Shari'ah mystical thoughts who believes seeking the guidance of the Shari'ah as a way of treating moral diseases in the community. He is the advocate of establishing the justice in society and creation of unity among peoples and with the spirit that is devoid of any religious prejudice, put the basis on peace and compromise with the followers of all religions and sects. He looks the same at Zoroastrianism, Christian, Jew and Idolater, and Muslim. And he writes, "Submissive of anywhere is dear. It may be among the Zoroastrianism and the Jew and Christian

and the wicked wherever are wicked, if it is in the Kaaba". He spent most of his life on the awakening of the audience and in a fight against ignorance and Sufi seeming of the Khanqaha, cortical mystics and erudite seeming of his era.
\end{abstract}

Keyword: mystical-ethical-philosophical thought-Ahmad Jaam

\section{RESUMO}

Se olharmos através da história da humanidade, perceberemos que este planeta tem sido o berço de seres humanos que, apresentando seus valiosos pensamentos, criaram mudanças na vida da humanidade. Um deles é Ahmad Jaam, cujos pensamentos morais e filosóficos não têm sido alvo de grande atenção, o que levou ao fracasso em identificá-lo e apresentá-lo em alguns dos livros importantes de homens teosóficos e pensadores iranianos. Portanto, este artigo motivou a introdução de seu pensamento e mentalidade. Ahmad Jaam é um pensador social e reformador e um sufi e crente puro, um homem liberto com pensamentos éticos,

\footnotetext{
${ }^{1}$ Phd of Philosophy, Academy of sciences of the republic of Tajikistan. Irã, República Islâmica. E-mail: yousefisaeed14@yahoo.com
} 
filosóficos e místicos da Sharia que acredita buscar a orientação da Sharia como forma de tratar doenças morais na comunidade. É defensor do estabelecimento da justiça na sociedade e da criação da unidade entre os povos e com o espírito desprovido de qualquer preconceito religioso, apostando na paz e no compromisso com os adeptos de todas as religiões e seitas. Ele parece o mesmo no zoroastrismo, cristianismo, judaísmo, idolatria e islamismo. E ele escreve, "Submissos de qualquer lugar são queridos. Pode ser entre o Zoroastrismo entre os judeus e cristãos e os ímpios onde quer que sejam ímpios, uma vez que está na Caaba". Ele passou a maior parte de sua vida no despertar do público e na luta contra a ignorância em relação aos Sufi do Khanqaha, místicos eruditos de sua época.

Palavras-chave: pensamento místico-ético-filosófico-Ahmad Jaam

\section{THE TERM "SUFI"}

There were many opinions about the meaning of the Sufi word for the mentioning of all their views that are beyond the reach of the discussion of this article. Many scholars and thinkers have discussed this in detail in their valuable works, such as Dr. Ghassem Ghani in the book of "the history of Sufism in Islam", pages 45 and 127, Professor Jalal al-Din Homaee in the book of "Sufism in Islam", page 69 and Abdul Kareem ibn Awazen Qashiri in the book of "Qashirieh", page 468, Haj Zin Abedin Shirvani in the book of "Riyadh al-Sayyahat", page 306, Abolhassan Hajviri in the book of "the discovery of al-Mahjub", pages 34 and 35, Shahabuddin Omar Suhrawardi in the book of the "Awarif ulMaarif", or "The Knowledge of the Spiritually Learned", page 50, Mohammad Javad Tehrani in the book of "What does the mystic and the Sufi say?", page 8. However, from the sum of the study of the works of the elders mentioned about the terms "Sufi", "Compassionate" and "Sufism", it comes out that the group that has been linked to taste and illumination, and not to proof and logic in discovering the truths of existence, named as "Sufi" and the way they have taken to reach to the truth is the "Sufism".

Background to the genesis of Sufism in the presence of Muslims

In general, there are three theories about the origins of Sufism and Islamic mysticism and the time and place of its genesis. 


\section{A. The first opinion - The reaction theory:}

The reaction theory has been expressed by some researchers and writers such as Richard Hartmann, Max Horton, Qasim Ghani, and Ahmad Kasravi and others, among which Dr. Ghasem Ghani is considered Sufism as a reaction of Iranian (Persian) thought to Arabic Islam. He believes Muslims have introduced Sufism to Iranian in the early centuries, further explained in greater detail in the book "The History of Sufism in Islam" (page 4). In contrast, Ahmad Kasravi who is a critic of Sufism presumes that as the result of Mongol invasion. For more information refer to the Sufism book, pages 11-14.

\section{B. The second opinion - The theory of borrowing:}

Some intellectuals believe that Islamic Sufism is a result of the thoughts of other nations that I called it borrowing and divided it into several categories.

\section{1-THE INFLUENCE OF NEW PLATONIC PHILOSOPHY ON ISLAMIC SUFISM}

A group such as Nicholson and Ahmad Kasravi considered Islamic Sufism to be influenced by Greek philosophy, especially the New Platonic philosophy, and believe that its influence and a series of other external influences made Sufism in a shape that in some cases the elders of Sufism were excommunicated and murdered. After this impact was that the Sufis, in particular, Ahmad Jaam, followed the appearances of the Shari'ah, and went on to adapt Sufism to the interpretation of the Qur'an and hadith which one of the most striking examples of these works is Ahmad Jaam's books. He expresses many of his ideas and teachings, such as: the truth is beyond reason, the unity of existence, the belief in the trivial parts, the downward movement and the reverse (Ascending), the path of spiritual journeying and its degrees, the enthusiasm of the soul in the corporality, the journey in itself and the purification of the human soul and the love is influenced by the New Platonic philosophy. 


\section{2 - THE EFFECT OF INDIAN THOUGHTS ON ISLAMIC SUFISM:}

Some researchers in Sufism such as Nicholson in the book of "Islamic mysticism", page 41, Dr. Ghani in the book of "the history of Sufism in Islam", page 155 and the book of "a discussion in Sufism", page 26, Ma'rouf al-Hassani in the book of "Sufism and Shi'ism", pages 317 and 318, Kasravi, in the book of "Sufism" and ..., believe that there are many similarities between Islamic Sufism and the habits and ethics of the Buddhists and Indians, to the point where some of them considered Islamic Sufism born from Indian thought.

\section{3 - THE IMPACT OF CHRISTIANITY ON ISLAMIC SUFISM:}

Some other researchers in Sufism such as Nicholson in the book of "Islamic mysticism", page 35 and Jami, in the book "Nafahaat al-Ons", page 131 and Kasravi, in "Sufism" book, believe that monasticism and Sufism are not only inferred from the teachings of the Bible, but also its most important teachings are in accordance with the spirit of Christianity.

Ahmad Jaam al-Nameqi (Žand-pīl)

Ahmad Jaam is known as Ahmad Žandepill (the colossal elephant) of the elders of the mysticism of Iran in the second half of the fifth century. Ahmad Jaam is said to be his hometown in the province of Jaam, or because honey was flattered by the command of God in His Cup, or that he was drunk in the loving cup, saying:

"Ahmad be drunk in way of love, to say Ahmad is Jaami."

He was a brave man, and he was illiterate in youth, and he was excessive in drinking, as he wrote: "I did not know about a variety of sciences, and I could not read al-Hamd and I could not do two Rakat of pray." At last, at the age of 22 , he gets fascinated by God and becomes Sufi and tried to worship and austerity went on the mountain. His name is Sheikh alIslam Abu Nasr Shahab al-Din Abu Nasr Ahmad ibn Abi alHassan ibn Ahmad ibn Muhammad ibn Jarir ibn Abdullah al-Lith al-bjeli al-Nameqi al-Jaami and surnamed to "Žand-pīl" which means: great, massive, tremendous, and has been used successfully. Farrokhi Sistani has used "Žand-pīl" in the place of the great large elephant, which its Arabic is alive elephant: 
Sometimes you bothered by bringing Žandepīl, Sometimes tired of bringing Rhino.

And also Manouchehri Damghani also used the same meaning for the word "Žand-pîl":

You said that every time Žandepīli, tremble from the pain of the Mosquitoes.

In his lifetime, it's not clear whether anyone has called him Žand-pīl or not. And it's not clear when and who has titled him. Some people believe that because he was tall and strong and vigorous, or perhaps because of his superiority to other young people in a village in his youth, he was later called Žand-pīl. But Dr. Ali Fazel believes that naming him by this name is due to the mystical affection and strength and high standing of his clergy in the leadership of the elders, especially in the preaching and remembrance of the master of conduct and noticing, and the purification of criminals with hatred and unhampered action. At any rate, Hamdullah Mostoufi and Qasem Anvar have mentioned him in his works by the title Žand-pīl.

Ahmad Jaami who you called him Žand-pīl, you can't defeat him even by fire.

Khajeh Abdullah Ansari (d. 481 AH)

Ahmad Jaam has benefited from the thoughts of the elder of Herat and has had a profound influence on his ascetic mysticism. However, what distinguished Ahmad Jaam from him and can be considered as an independent mystic are his social perceptions of mysticism and his critical look is to other mystics, because Khajeh Abdullah Ansari has only spoken of Shariah ascetic mysticism, and has tried to make precise and scholarly definitions in his holy authorities and to curtail those authorities. However, in his mysticism, he does not have a critical view of the mystical forms, and with great efforts and diligence, he expanded the scope of mystical concepts and, with special elegance, has defined the boundary between concepts that have close meanings, but mysticism Ahmad Jaam is sociological and cognitive critique of issues related to Shari'ah and truth, science and action, wisdom and its limits, and the explanation and description of authorities and the status of the elder of herat's thoughts are of great interest, but Ahmed Jaam authorities are different from his degrees and stronger from the point of Socially view.

Abu Saeed Abu al-Khair (d. 440 AH)

Khajeh Saddid Al-Din Mohammad Ghaznavi writes in Ahmad Jahan's authority: Ahmad Jaam has a spiritual relationship with Abu Saeed Abu al-Khair, and his cloak has 
come to Ahmed Jaam with several mediators. But Professor Dr. Shafie Kadkani put him in front of Ahmad Jaam and proposed reasons for this claim, and writes: Abu Saeed Abu alKhair met with the master of all religions with friendship and tolerance and believes that he knows all the servants of God as human and brothers and equal, while he knows Ahmad Jaam lacking this, and in the proof of this claim, he gives the following example:

Alas! I have no power, to hit the Materialists.

And he explained that Ahmad Jaam has condemned all those who do not think like us to death, and knows the author of the authorities as a liar and the story of the soul of Abu Saeed that has come to visit Ahmad Jaam (from the book of Ahmad Jam authorities), is a false Legendary.

Ahmad Jaam's position among the scholars and clerics of jurisprudential and theological religions and the mystical participation of the era

\section{A. Those who have mentioned Ahmad Jaam in their works}

The word Sheikh Jaam in works of other poets

This term does not have a high frequency in the other poets' poems, so that in the Divan of many of the poets that were studied and searched, except for the poetry of Hafiz, only six bits were found, which have the same term in their poems, the three bits of which belong Ahmad Jaam, Molana Nourodin Abdul Rahman Jaami:

There is no Sheikh like Jaam for the disciples of love, good for the one who shakes devotion hands with Sheikh.

Ask a cup from Sheikh to sustain grace, which from his ethereality the mystics' joy is constantly.

If at the time a cup attains to the Sheikh, where to repent of wine around his lip?

Mohammad Asiri Lahiji makes his case:

When you will be aware of Sheikh Jaam's conditions if you don't know Abu al-kheir.

And of course, once the master Malek al-Shoara Bahar in a poem addressed to Dr. Souratgar, has given the title of Sheikh Jaam to Nour al-Din Abdul Rahman Jami.

That King of utterance who after the era of Sheikh Jaam, the territory of the poet will not crown.

Some of the poets have also mentioned Ahmad Jaam as the elder Jaam:

If Sufis should choose an elder, there is no one more devout than elder Jaam. 
As noted above, the six bits found in this case refer to Ahmad Jaam directly and one bit dedicated to Nour Al-Din Abdul Rahman Jami.

\section{Wisdom}

Contrary to the notion of those who have attributed Sufism to the opponents and contumacious of wisdom and have written in support of their claim: Another sin os Sufis is the hostility they have shown with wisdom. Wisdom is the most precious given of Allah, and whoever should recognize it and make it the guidance in their works. They have shown enmity with it because their works are unwise, and have spoken the language of demonstration:

Love came, his wisdom became displace, as the morning came, the candle became unproductive.

Our Sheikh told us when a Sufi asked, what is wisdom? Our Sheikh said: "The wisdom is the instrument of worship, with the wisdom the secrets of the lordship cannot be found that he is a breeder and the breeder is not persuading the past."

But Ahmed Jaam believes that "the first thing that was created the God was wisdom, and first of all, it was wisdom that was made up of the truth of excellence" and his force, he says, holds back from maladaptive things. In many cases, he believes in the validity and reason of the guidance of wisdom, and introduces that as complementary to religion and Shari'ah, therefore, he introduces it as "Sepah Salar", and, along with the light of guidance and knowledge, is one of the four things necessary and important to enter the valley of Islam, and recognize it. The people of speech said: "Mind is a simple essence that recognizes things by their own rights" and warns Muslims from entering to the path of monotheism and theology and the recognition of the higher attributes of excellence without it, as he writes: "But if these four things are not with him, it's better not to come in this path, because this is not a way to be Muslim."

He speaks about the value of "osmose" in the fourth chapter of the book of Bahar alHaghighat, and writes: "We should know that there is nothing beyond osmose and affection." He further introduces the aim of osmose as the inmate of Osmose and he introduces the Prophet Muhammad Mustafa (PBUH) the abstract of Osmose. He goes on to talk about the creation of the intellect and points out that God has embedded the light of poverty and osmose and guidance in the light of wisdom. And then he writes about its importance: "So he said: To 
my dignity and glory, that I created no people, dearer than you. I am proud of you and they will recognize me with you. "

If we want to consider the comparison of the position of wisdom with the Shari'ah and religion, Ahmad Jaam introduces the wisdom in a lower position than religion and the Shari'ah, and even as theologians in the service of religion, as it writes: "And not the Prophet (p. ) Was of wisdom, but it came from the light of wisdom and ethics of Mohammad Mostafa (peace be upon him); and that light is the light of Osmose, not the light of wisdom; and the reason is that: if it were the light of wisdom, then, wherever it was, it should be that almighty, so then, for wise men this verse will come: As Almighty saying: "These are the evil of the land." Or elsewhere he says: "It has come that: the first thing that God was created was this wisdom. But be aware! That no creation had overtaken the light of Muhammad (PBUH)."

The important point about Ahmad Jaam's belief about wisdom is that he considers the power of wisdom needful to be guided by the unseen and devout world. Because in his opinion "the reason for this is that if you were an intellectual and a sentimental wise, then you would know wherever it was, therefore, there are thousand of thousand wise people who do not know the truth of right, whose wisdom speaks of all creatures and does not recognize Almighty God, and many of these clerics and low minds who know God so that many who have the name of Khaje Emami know that!" For him, the tool for knowing the wisdom is sensory (the sensory organ of the human being is also weak and in many cases makes mistakes in understanding the problems of the world around us). Therefore, in his view, if the wisdom of the savant is no end to divine science, not only become the agent to guide, but also leads to human misconduct.

Righteousness and magnitude

Predestination

In the case of Divine righteousness and magnitude, Ahmad Jaam believes, according to the divine destiny, the destiny of man is already predetermined and writes: "Almighty Saying: And God will do whatever he pleases and judge what he wants; the day we judged and We predestined, you were not. We made it as we wanted, and there was no desire for it. Today we will do the same as we want, and there will not be any desire. Tomorrow will be the same, that we know yesterday! No one is against this problem, and all is right and there is no wrong and no one in between. " 
But this determination is not in conflict with human discretion, and human beings are free because God has determined the human destiny on the basis of man's choice and authority, and human beings are in self-dependent verbs. "The seventh rule is that you confess that you can afford the servants of God. Can do what they can and can not."

Predestination has two meanings that according to these two meanings, it is possible to say that predestination is of two kinds and as it is from the works of Ahmad Jaam, he has referred to predestination in both terms and meanings in his works.

The scientific Predestination: In the afterlife of old science, and on the wisdom of eternity, and on righteousness, and predestination, and volition, and old devotion, has created something that is a particle of the past, that will not be more and less or a little bit before and after, and to the amount of a mosquito will not be overtaken by virtue of the benefit of which is not his old science, and whatever you do and will do, it will be from this tale." This kind of predestination is not in conflict with human discretion, but during and in confirmation. Further explanation is given in the footnote.

The objective Predestination: Think as the right of subjection and transcendence says: "We divided among them living in the minimum of livelihood of the world. We have divided among you livelihood, we put on one another more. If anyone wants to make any changes and convert our destiny, he can not. Although all the first and last creation will be made on one task and one thing, they will not be able to push a part of our destiny more or less and to push ahead. If our brothers keep the advice of their brother, and they will not be deceived by these proverbial people of Satan and the deceived world, and they will not be spoiled for greed. "

\section{Righteousness}

Righteousness means ending up and completing the work, and the final stage of work can also be called righteousness. The righteousness has the same meaning as the predestination of the two terms: "scientific righteousness" and "objective righteousness". Science is the end of work and the final stage of a verb of "scientific righteousness", "If no one came to God's righteousness, and if he could escape his righteousness, you would be secondary."

The scientific righteousness of God; that is, God's knowledge of the eventual occurrence of phenomena. This scientific judgment of God does not contradict human authority, because God has the knowledge that a phenomenon or action with the will of man will certainly occur. In other words, scientific judgment of God of human verbal actions, 
means, God knows that the verb of man will definitely happen with the character of selfdetermination.

The objective righteousness of God means, the assignment of the objective realization of phenomena to God. In other words, the proper objective righteousness of God is that we consider the existence of phenomena from the beginning until the end of life, but from the time of provision of the preliminaries under the wise divine guidance, and to provide the conditions for the emergence and the final stage to be documented, we will count him of his will. In the third sentence: 1. Attainment of any disability to the extent of the essential necessity through the realization of its ultimate cause; 2 . There is no creature of independence in existence and existential effects; 3. Naturally, the necessity of all phenomena is documented in God that it will be almighty with richness and absolute independence.

In this regard Ahmad Jaam quotes a poem of Ferdowsi on the following:

Why are you pursuing to build the world, the world has already made by God.

In fact, the objective righteousness of God requires the fact that - as the existence of any phenomenon of assignment to the permission of God's developmental form and without the permission of him does not exist any creature in the realm - as well as the emergence of anything documented in the judiciary objective is divine, and without it, no creature has its own special shape and limits, and eventually it does not exist.

However, it is a man who, in keeping with his existential attitude, was content with the Lord of the world with divine righteousness and imperceptibly surrendered to the divine.

Seeing God at the Resurrection Day

Regarding the sightings or lack of sight of God by the believers at the Resurrection, Asha'ereh and Mo'tazeleh and Shi'ah have a special opinion on it; Ahmad Jaam, a Sunni Hanafi religion, and verbally similar to Asha'ereh, believing in Seeing God at the Resurrection Day, he writes: "Seeing God at the Resurrection Day is a right to believers." Therefore, he argues that the Prophet's (PBUH) message that God is seen on the Day of Resurrection as seen on the fourteenth night of the month, and that as the sun is seen when it is not clouded against it, they will see the believers of God and do not see the disbelievers of the Lord. "The sixth rule is that confessing that you can see the truth and the excellency of God's paradise, do not be so glaring at all, and it's not a face and a body of wellness and quality, but to see how, as you know today, How and why, 
He introduces the reward of Osmose and knowledge is the sight of God at the Resurrection day, as he writes: "Osmose and its light from throne and empyrean, and of bred and pen and from jinn and ons, of kingdom and earth, of sea and land - and of Whatever is and is created by God, the light of Osmose is more sophisticated than all; and all that magnitude and prestige is that he is the price of glory and vision."

Moral disastrous

The truth of Good Moral:

Ahmad Jaam believes that man can be good-natured, so he can be disciplined and educated, because advising the children and austerity are all for discipline, and the Prophet (PBUH) has said that "Improve your morals." He knows austerity and hardening of a human soul, one of the most effective ways of cultivating human temperament are to be purified from self and self-esteem. As he writes: "And the man who becomes a man it is with austerity, and the austerity is to stay away of lust, and the God said us about lust, where he said: "keep your soul from lust, so indeed his place is in heaven."

In blaming those who do not seek to cultivate their own soul and moral, the ugly and filthy nature of the human soul is likened to the ugliness and neglect of the dog, as it writes: "The instance of a capricious man, is like the instance of a dog, as God said: He followed his lust like a dog. As far as he said: Perhaps they will think of it. The Prophet said: "The people are intellectual, or the student, and whatever else is a beast fly." Now, the Prophet (PBUH) said: "Anyone who does not feel the pain of learning is like a beast fly."

In his beliefs, the cultivation of the human soul worth a lot and he believes that if human moral are not corrected, there is not much difference between humans and animals. In his view, the human is like a white plate, which is painted with moral education. Therefore, the mood that man can develop in himself is divided into two parts: the first external ethic and the second internal ethic.

\section{The Truth of human external ethic:}

1. Having the insight: He considers the Dos and Don'ts bound to insight. In his view, the work and action of a person have value and credibility that is sufficient from insight. "Everything that one does, not on insight and not on truth, ask to do or not to do."

2. Saying the Right: He considers saying the right to be a human's ornaments, and he himself has consistently been right talker, right viewer, right eater and he did not care to say bad about others. 
"Today, speak right is very difficult work; and more difficult than that is anyone's right to hear, and can be heard in this time! It is the right to hear the right, and say the right is difficult that this era is an era of oppression."

3. Solving People's Problem: In comparing the two assumptions, he prefers the work of the people to the Creator preferentially, and writes: "If there are two assumptions, then one is God and one is the creation, what is God, and Take what it is people, because servant is weak and God is powerful; the weak is the first to be kept."

Of course, in this regard: this view is not accepted in absolute terms and in all cases, but it should be considered in the premise of the work of the people on the work of the creator or inverse of those circumstances of the time, place, and states of the individual. For example, if the right of creation and the creator's right belong to the deceased's property, then the right of the creator, zakat, on people, ie the inheritance is prior.

4. Pudency: Ahmed counts the pudency from best morals and mentioning it in the Hadith of the Prophet (PBUH) in this regard: "Every religion has a moral, and the moral of Islam is pudency". And elsewhere he writes: "Shame is from faith". Also, the Prophet (PBUH) says: "It's half of the faith to have shame."

5. Do duplicity not: In most of his works, he mentions duplicity evil and considers the condition of accepting prayers and worship far from the duplicity. "Do not be so, if you worship so all the world will see you and know you and you Produce! And if you give charity, everyone must know! ...»

\section{The Truth of human internal ethic:}

1. Science: From the viewpoint of Ahmad Jaam, the science is a human's ornaments that man must have at least as much knowledge of the right of falsehood and of the truth and the good speech of the ugly.

2. Wisdom: One of the most important aspects of Ahmad's attention and emphasis is the wisdom and the pursuit of that, which he considers it continually useful with companionship of science: "And no right works come to mind unless with dear and noble science, But if wisdom is not with science, anything will not happen!"

3. Good intentions: He considers the correct intention to be one of the most important moral adornments and considers it a condition for the acceptance of human actions. "And this is about the intention of what is the intention of that person. And if he has the right intention 
and with proof, he is right, and if the intention is not correct and he does, his work is with the God of excellence."

Heart and soul

The multidimensional nature of human and the fact that man is the only material object, or in addition to another nonmaterial dimension, has long been the subject of discussion by most intellectuals. What most intellectuals have thought spirit, corpus, heart or soul as one. Ahmad Jaam, unlike Ibn Sina, Ghazali, and the Sanaee Ghaznavi and Attar, considers a man with three dimensions: one dimension of the material that he calls the corpus and visible, and the second dimension the spirit and the third dimension of the heart. "Man is on three orders: he is the corpus, and the spirit is, and the heart."

Worldliness

Blaming the world

Most scholars find the thing is not obtained by solvent, should be blamed only. Dr. ZarrinKoub writes about worldliness: "They suspect that human salvation is in leaving of the world, and they do not know, what is the world which is denied in the Quran and Hadith." But Ahmad Jaam does not consider the purpose of human creation to be anything other than worship. According to him, man is in the path of his life to reach the head of the purpose that eternal bliss is bound to go astray except in the path of divine and following the Qur'an and the tradition and Knowing that the divine power of God and the world are contradictory, the community finds them almost impossible. He writes: "But the elders of religion, and commentators, each have said something, and they are all good, but we promised to insist that: "Worldliness is of the corpus," because whatever is in the world are all desires of the corpus, and this continuously conflicts with the dear God. And those who have said that: "the world is inferior." This is true; it means: "inferior" - that is: loving the divine God and loving the corpus, both of them are not right together; As God says: "keep your soul from lust, so indeed his place is in heaven."

What is the cure for the snobbery?

By reading the works of Ahmad jam, he shows 5 effective method for curing the snobbery to his followers and explains them so:

1: training human soul

He knows training human soul as one of the most effective ways for getting rid of snobbery. 
2: endeavor

By explaining his followers, he knows endeavor of the action as the second way for curing the snobbery and says : o my brothers, listen to my advice and don't be pride because of satan and your camal desires, since you become sotty.

3: divulging the requirements to god and asking the necessities from him

He believes that divulging the requirements should only be from the god which reduces snobbery, because god is self-contained and all the creatures need him.

4: commingle with good peoples and avoiding from indecent persons

He believes that if human behaves correct in this important option, is comfortable all his life and talking and commingling with pious persons prevent human from adversity and remorse.

5: remembrance of pandemonium and death

He believes that remembrance of death leads human to kindness and notice to other world.

Getting good and bad

The important case is that human should know that the attractiveness of the world is much and leads to misleading and perversion .

Convetousness and its cure

He introduces convetousness as a false thing that hasn't any sincerity and truth.

Greed and its cure

Greed is a pain that its drug is the bitterness of patience and sweetness of knowledge and difficulty of action. Greed is like fire that burns with wind and destroys all human assets.

Remedy of greed

He proposes several methods for curing greed in human :

1: reduce his expense and content to what he has .

2: don't have covetousness and be patient .

3: if found the expense for today, don't think about tomorrow .

4: don't collect a lot of money .

5: don't forget the death .

Generosity

Generosity is like a light that as light kindles its around and warms the house. generosity also kindles the society and helps the poor and promots humanitarian activities . 


\section{The badness of hypocrisy}

Increasing the movement of ascetic at the beginning of third century, promoted the motivation of pretending to be believer and led to the situation that with crying and reading holy qur'an in the society, showed their repentance and regrat. One of the worst attributes is hypocrisy which means saying a thing by tongue and aiming something else .

1:Hypocrisy in body

It happens when for example one make his face yellow so that people think that he hasn't slept the night before . such a person hasn't any honour and glory in presence of god.

2: hypocrisy in talking

This hypocrisy happens when a person has vain egotism in society so that all the people know that he is lying and make fun of him.

3: hypocrisy in worship

It happens a lot that some people work for themselves but claim that we are working for god and people and if muslems need them, don't pay attention to them.

4: hypocrisy in showing worship

Ahmad jam writes beautifully that some people have decorated and and false appearance and show that they are obedient of god and his prophet but if you pay attention to their activities, you understand that they are just pretending and are deceiving people .

Remedy of hypocrisy

Ahmad jam says that the only cure for hypocrisy is doing works with divine aim not for showing to people . liking world is very dangerous and salvation from this situation is lack of relish to material things

What is virtue?

It means that human places himself lower than his social position and on the contrary, pride means contest and knowing himself higher than his personal and social position.

The virtue of humility

Humility has good effects and results that knowing them can encourage human to get them . if human be humble towards god, it helps him from satan .

Pride

One of the worst moral attributes is that someone knows himself better than others and in holy Qur'an it has been blamed. 
There are a lot of people that worship as if they are creditor from god and forget the true worship and go towards pride but Ahmad jam advice them to be humble and meek.

Pride for beauty:

There are many people that are enchanted to their beauty and are proud against other persons . Ahmad jam writes : don't become proud because of your valuable dress and instead of it, pay attention to your activities .

Pride for wealth :

Ahmad jam reminds human about the deposit from the first day because god stressed in qur'an that I put my soul in human .

Remedy of pride:

One of the best ways for curing peide is self-examination, because if you know what you have been at first and in the middle and what you will be at the end, never become pride .

In the works of great authors of moral, haughtiness is one negative attributes that made satan so damnable and outcasted from presence of god .

Effects of haughtiness :

One of the effects of haughtiness is that human sees his sins unimportant and also thinks he is impeccable because haughtiness prevents him from seeing his wrongs.

Remedy of haughtiness :

Until you don't cure your haughtiness, you can't reach to human accomplishments and personal and social progresses, so Ahmad jam believes that most effective way for curing haughtiness is ignoring worships by human .

Moral saviors : religious law - rule of life - truth

Almost during all the Sufism history, the ways for mystical evolution of human can be seen in three phases : religious law - rule of life - truth .

First phase : religious laws are devotional affairs that god has fixed for humans by explanation of prophet of Islam but many Sufis have been misled because of not understanding it very well .

Second phase : rule of life belongs to wayfarers of the way of god . they must believe that all the prosperities and guidances are because of blessings of holy prophet of Islam( p.b.u.h.). 
Third phase : rule of life ends by walking in the last phase which is route of truth. Truth is a place that is the position of proximity. It means that a perfect learned gnostic ignors himself and just sees god and no one else .

First element of repentance

In Islam and Ahmad jam point of view, repentance is very important and in his book named key to paradise, he explains about his son najmedin abobakr who stopped doing rotten activities and became penitent and Ahmad jam advised his followers to notice to fate of his son as an example .

Three phases of repentance from Ahmad jam point of view :

As khage abdollah Ansari, Ahmad jam also believes that repentance has three pillars which are: remorse by heart, excuse by tongue and stop doing sins by body and anyone who obey this order, can become one of the good friends of god .

So at first, the penitent person should be regretful by heart from the sins he has done and then, he must tell by tongue that he is remorseful and in the third phase , the penitent person should compensate the destructive effects of his sins and if has spoiled the rights of other people, commute them .

Different kinds of repentance from Ahmad jam point of view :

Any of gnostics have their own classification about repentance . for example mostamli bokhari devided the repentance to three positions that are: general, special, special special . general repentance is regret of sins by tongue and heart but special repentance is going towards god and seeing nothing except him.

Repentance of obedient

It is like a pearl that most of the people don't know its value and only few persons can reach to it and a lot of sins are forgiven by it. He compares the heart that has sinned, to a dead heart that its only way to salvation is repentance

Repentance of sinful :

Human should know that what makes curtain between him and god, is doing sins and what destroys sins , is repentance . human heart is like a pure and clean pearl that with any sin, becomes dirty and repentance makes it clean again .

Repentance of gnostic :

Ahmad jam says that repentance isn't only for impures , because repentance is so good that it is necessary for anyone in any position . he believes that all the people need repentance 
and best persons were prophets and one of them was yahya who was penitent when he thought he has done something against the satisfaction of god .

Ahmad jam believes that repentance is different for various persons, so he proposes special kinds for different people and he says the most simple of them is repentance of external corruption, so that a person should save his tongue and eyes and ears and other organs from doing sins .

Patience and thanksgiving :

Mostamli bokhari writes : because asceticism means leaving wishes and this can't be done except by patience. Ahmad jam believes that a person who is wayfarer and wishes to clean his soul, must be patient in happiness and sorrow and in wealth and deficiency . wayfarer should avoid of complaint and must be submission to the orders of god and this is the position of resignation which is higher than patience and a patient person reaches to the position of satisfaction .

\section{Thanksgiving :}

Thanksgiving is imagine the blessing and showing it in talks and actions. Thanksgiving with heart, tongue and action has come in Islamic narratives too. Ahmad jam not only knows the blessings from the god, but also sees the calamities from him, so if ordinary people bear the calamities, Ahmad jam thanks god for it.

Why Ahmad jam thanks god?

He thanks god for following reasons :

1: thanking god is because of first and gradual creation by god, since he is the only creator that has brought human from non-existance to existence and gave him wisdom and elected him as the noblest of creators and human should thank god for all these blessings, because I am a clear-sighted, hearing, speaking, learned muslim .

2: because only god can birth and kill human and sleep is like death, and Ahmad jam says when human is sleeping, is like a dead person and when he awakes, it seems that he has been created again, so human should thank god for all these blessings

God has given us many blessings so if his worships continue for all nights and days , isn't enough since he can't even thank little bit of the blessings of god .

Fear and hope : 
Fear of god has a direct relation with safety of punishment of resurrection and as Ahmad jam writes : if a sinful comes to presence of god, while he is penitent, it is very better than the worships that are with pride and haughtiness .

Different kinds of fear:

Ahmad jam has divided fear to 5 kinds as follow :

1: fear : this fear is for sinfuls and impures and god in holy Qur'an says : the person who fears of place of the god, has two gardens in paradise .

2: humility : it is a fear that comes with reverence and usually it arises from knowledge, so true scholars have such fear .in holy Qur'an , god says about such group: only divine scholars fear of god and Ahmad jam explains them as follow : a big fault is that when a person fears of someone else, dose not want to see him and is running away frightened.

3: urbanity : a fear that is in the heart and belongs to humbles because of not doing service . holy Qur'an says : those who when god issue called, have humility in their hearts and are eager to meet their god

4: curstsy: it is a fear with agitation and distress which belongs to worshipers, because they know themselves guilty in presence of god . holy Qur'an says : they call us with fear and hope.

5: majesty : a fear that comes with glory and homage for god and belongs to gnostics, because god is watching and warns worshipers of disobedience, because people return to god

\section{Roots of fear :}

Ahmad jam believes that roots of fear are in three aspects :

1: knowledge of god :

Ahmad jam writes about the importance of knowledge and recognition of god : be aware that the essence of all the things is pure unification .

2: fear of activity:

The other factor for divine fear in human is fear of justice of god . if someone has worshiped all his life, god can torture him for a sin, so the bodies of pious people become weak and thin because of fear of god .

The effects of fear of god :

Ahmad jam believes that fear of god has a lot of benefits but most important of them are 3 followings: 
1: abstinence from sins :

Fear from god, modesty, chastity bring abstinence from sins for worshipers, so this fear is like a spot on the face of a pious and his honor medal .

2: safety from torture of pandemonium :

Fear of almighty god, leads to prosperity of future life and safety of pandemonium in other world . holy Qur'an says : the person who fears of god and dose not sin, his place is certainty in paradise. Ahmad jam advices his friends as follows: I oath to god, if you associate with persons who caution you today to be safe in resurrection day, is better than to be safe today but timid tomorrow .

3: believers are fearful and also hopeful :

True believers as are fearful of god, are only hopeful to him and not anyone else . god sees and knows and hears anything you do and say and think, so be aware of your activities , so that not to be remorse in resurrection day.

4: avoiding of dispraise mendicants :

Although politeness and culture of Sufism in thinking and talking include important human and moral values, but it doesn't mean that all their culture are defendable and suitable to follow, so Ahmad jam showing standards for good and bad mendicants, warns his friends of insulting true mendicants .

Qualities and signs of false mendicants from ahmad jam point of view :

1: they aren't pragmatic .

2: they are camal desires .

3: they aren't faithful to true Islam and religious law

4: they decree anti-Islam judgments.

5: they haven't the knowledge to distinguish between true and false but claim to be leaders of people.

Qualities and signs of true mendicants from Ahmad jam point of view :

1: they believe all the things are only from god .

2: they have chosen only god and their aim is to become closer to god by true worship

3: they are always followers of Islam and religious law.

4: they have ignored the outward world .

5: they shelter in mountains to improve their self-regulating activities . 
Principals and analyze of blaming ideas :

Fierce struggle with pride and haughtiness of human is from the principals of blaming party . humiliating essence in all the situations, either desirable or undesirable is necessary .

Virtue of amazement :

Mostamly bokhari writes about amazement as follows: the first amazement of gnostic is because of god activities . ahmad jam also writes : we came to fourth position which is superior position and is amazement position that the gnostic listens everything but says nothing and behaves like a deaf and blind and dumb and irrational, because he knows that : the person who recognizes his god, becomes silent .

The truth of amazement :

If you ask Ahmad jam what is the meaning of amazement? he gives this answer : it is a pain that arises from heat of love . heart burns and if you pour water on it, it burns more and anyone who has this pain, reaches to high position . ahmad jam believes that amazement is the tool of fondle of god and the way of training the human by his grace and kindness .

The way to reach to devotion :

Ahmad jam proposes three important activities for reading human to devotion :

1: the person should have the necessary faith which means the belief to god, resurrection day, prophet, divine books and angels .

From Ahmad jam point of view, an action has value when is with pure faith and belief in god.

2: the person should be compel and obligate in his activities with the orders of holy religion .

Ahmad jam says : when you do your work with devotion, it should be according to the orders of god and his prophets and you should avoid whatever they prohibit you.

3: in worship and divine affairs , human should have a pure and clean purpose for god

The final extent of devotion, as ahmad jam says, is doing the activity without prospect to any wage or reward .

The truth of trust :

Ahmad jam believes that the position of trust is the highest place for esteemed people, but its understanding is very difficult and doing it is very hard .

Unification : 
Unification is the most important and most fundamental pillar in divine religions . ahmad jam explains it beautifully : be aware that unification is the highest position and honor for prophets and variable for masters.

Excellence of unification :

Ahmad jam explains the importance of getting knowledge of unification as follows: I studied all the subjects to see which one is better and most useful and finally I found that it is the knowledge of unification, because almighty god and holy prophet are dearest in the universe.

The truth of unification :

Unification is one of the most important elements of Islam and in the shadow of it, the other worships are measured . in other words , all the moral and religious and human activities can have meaning under the existence of believing the god and pure unification .

Ahmad jam is a gnostic of unity of existence :

The subject of unity of existence in new-plato philosophy, has been interesting for Sufism more than other subjects, because the person who believes this philosophy, sees all the creatures as the mirrors that show the god and reach to eternal prosperity . a wayfarer must fly with love toward god and make himself free of the world and become mortal in the way of god, who is truth existence.

Deployment of Ahmed jam about comparison and standstill :

Ahmad jam during his productive life was careful and sentry of truth unification so that not to deviate from its real route, because in his time and even before him, there were people that had fallen in the trap of comparison and standstill . like mostamli bokhari who lived before him , ahmad jam tried to choose a middle and moderate way, as mostamli bokhari wrote : I studied to know what is middle way and I found the way of custom and community. The true route is suitable for all the ideas but the people who believe to comparison and standstill, go to wrong way.

\section{CONCLUSION}

If you study the human history, you will notice that the world has been the birthplace of training persons who by explaining their valuable ideas, have brought important changes in human life . one of these persons is ahmad jam that until now, his moral and philosophical 
and mystical ideas have not been noted and so, he has not been introduced in some of important books about Iranian scholars and in this article, we have tried to explain his ideas and thoughts.

Ahmad jam is a pensive and social reformer and pious sufi. He is a liberal philosopher who believes that the way for curing the moral and social diseases is seeking help of pure religion .

He is advocate of settlement of justice in society and creation of unity among people that with an excellent morale and without any religious prejudice, has put the element on peace and agreement with all the other religions. Ahmad jam looks the same to muslim , ghebre, Christian, jew and idolater and writes : the obedient is honored everywhere, even if he is among ghebre, jew or Cristian , and evildoer is cursed, even if he is in Kaaba. Ahmad jam spent almost most of his life in awaking listeners for fighting with ignorance of fanatics and misled people .

Ahmad jam suffered from pains and difficulties during his life . he lived in 5th century and like his contemporaries, elected a special mystical method which was different with the ideas of Abolhassan kharaghani and Abosaeed abolkheir.

There are differences between his gnosis with gnosis of Baba taher and Imam mohammad ghazali and he founded a new school of thought that a lot of his followers complied it, so that his convent wasn't just a religious place, but also it was a center for practical training .

Because he was a brave freeman and wasn't silent against cruelties of the kings and their servants, he invited his followers to fight with them. but at the same time, he penetrated in Seljuk court and with attracting their attention and admiration solved the problems of the people, so that this admiration continued after his death and because of their devotion, made beautiful buildings around his tomb.

One of the unique specifications of Ahmad jam is that he hasn't claimed that he is a writer or scholar or being Master in Arabic, but his effective and interesting books that have been written beautifully are still shining like a pearl on vertex of Iranian culture and literature.

Because Ahmad jam was popular among people and was also relative with powerful kings of Al-e-kart who ruled in Herat at that time, this situation led to splendor and development of Torbat-e-jam and this place changed from a small village to a palmy city. 
Although some of his followers knew him as a saint and have ascribed many anecdote and greatness to him, and some people have criticized him, but training the students like Hafez Shirazi and Abdorahman Jami and Abobakr Taibadi, is one of the great souvenirs of ahmad jam .

Abovementioned subjects were some examples of most important specifications of ahmad jam that show the greatness and magnificence of him in ancient and modern Khorasan.

\section{SOURCES AND ORIGINS}

Holy Quran.

Khoramdel, M., Holy Quran . noor interpretation Ehsan publication. 1379, Tehran: second editi.

Nahgol balage. Gohar publication[feyzol eslam, trans]. 1375, Tehran.

Lembton and etal, Islam history, translation Ahmad Aram, Sepehr publication. 1381, . Tehran :fourth edition .

Batote, E ,.Diary[Dr. Mohammad ali movahed, trans]. First and second. volums. 1370, Tehran :Agah publication.

Asiri lahigi,.M., interpretation of Golshan Raz. 1371, Fifth publication,Saadi publication.

Amin.mohsen, aayanoshie. Vol. 7. 1403, Beyroot.

Amini negad , A, Acqaintion with Islamic mystical 1387, Qum: Imam Khomeini publication.

Ansari, A.K., Kasholasrar. Vol. 10. 1371, Tehran: amirkabir publicatio.

Bergsen.hanry, moral and religion [ Hassan habibi]. Vol. First publication 1358, Tehran.

Bandar rigi. M, Arabic to farsi dictionary Vol. seventh editio. Islami publication 1370. darvishali, B., Rozatoryahin. With introduction of Dr. heshmatollah moayed.nasher publication. 1345, Tehran.

Beyhagi, A., beyhagi history. Ferdosi university bubliction, 1375. third edition.

Para bokhari. 1354: Tohori publication.

Tafazoli,A, Dervishes in molavi tomb.ziba publication. Vol. first edition 1370.

Javad.Tehrani, M., What says sufi?Khorasan publication 1340. 
Fazel, A.j.D.a., Farshive publication, 1387. First publication.

Shirazi, G.g.H. Zavar publication., Tehran.

Jaafar.S, Mystical dictionary, Seventh edirin. Hohoori publication. 1383, Tehran.

Jaafar.S ,Islamic dictionary, vol .Third, Fist edition. 1362.

Seraj, t., [Dr. mehdi mojtaba,Trans]. Asatir publication. Vol. first edition 1382.

Sanaee ghaznavi, M, razavi, ,t., publication. Vol. Seventh edition. 1388.

Shabestari. S.M., Explained by Dr. Mahmoud lahigi ed. S. edition. 1381, Tehran

Shoshtari. N, Magalesolmoamenin. Vol. Second. 1376, tehran: Eslamieh bookshop

Abedin.Ahirvani, Z., Reyazosyaha. Edited by asghar hamed. Saadi bookshop. Tehran.

ZabihollahSafa, D., Literature history in Iran, ed. F. publication. 1370, Tehran.

Toosi.n,. siasat nameh[ Ehsan yarshater], Nashre ketab. publication Tehran.

Ghazali toosi.A. kemyae saadat. H, k,. Katibeh publication.12th edition. 1384 ,Tehran.

Ghaznavi M., Modes of ahmad jam, Nashr publication. 1345, Tehran.

Ghani.G,. hafez works, Zavar publication, 1331.

Ghazvini. A,. Editing Hafez divan, First edition. Negah publication. 1372, Tehran.

Gooshri. A,. Translator hassan Osman, Katibe publication. 1383.

Azizi. M, idea of rationalism, 9 vol.1386.

Ghadrdangramaleki.,M. pagan in religion.

Mari shimel ,mysticism is a bridge among cultures. First vol. university publication. 1383, tehran.

Trabalho recebido em 06 de agosto de 2019

Aceito em 01 de junho de 2020 